\title{
Bimetallic Cooperative Cleavage of Dinitrogen to Nitride and Tandem Frustrated Lewis Pair Hydrogenation to Ammonia
}

DOI:

10.1002/anie.201902195

\section{Document Version}

Accepted author manuscript

Link to publication record in Manchester Research Explorer

Citation for published version (APA):

Liddle, S., Doyle, L., \& Wooles, A. (2019). Bimetallic Cooperative Cleavage of Dinitrogen to Nitride and Tandem Frustrated Lewis Pair Hydrogenation to Ammonia. Angewandte Chemie International Edition.

https://doi.org/10.1002/anie.201902195

Published in:

Angewandte Chemie International Edition

\section{Citing this paper}

Please note that where the full-text provided on Manchester Research Explorer is the Author Accepted Manuscript or Proof version this may differ from the final Published version. If citing, it is advised that you check and use the publisher's definitive version.

\section{General rights}

Copyright and moral rights for the publications made accessible in the Research Explorer are retained by the authors and/or other copyright owners and it is a condition of accessing publications that users recognise and abide by the legal requirements associated with these rights.

\section{Takedown policy}

If you believe that this document breaches copyright please refer to the University of Manchester's Takedown Procedures [http://man.ac.uk/04Y6Bo] or contact uml.scholarlycommunications@manchester.ac.uk providing relevant details, so we can investigate your claim.

\section{OPEN ACCESS}




\title{
Bimetallic Cooperative Cleavage of Dinitrogen to Nitride and Tandem Frustrated Lewis Pair Hydrogenation to Ammonia
}

\author{
Laurence R. Doyle, Ashley J. Wooles, and Stephen T. Liddle*
}

\begin{abstract}
Although reductive cleavage of dinitrogen $\left(\mathrm{N}_{2}\right)$ to nitride $\left(\mathrm{N}_{3}{ }^{-}\right)$and hydrogenation with dihydrogen $\left(\mathrm{H}_{2}\right)$ to yield ammonia $\left(\mathrm{NH}_{3}\right)$ is accomplished in heterogeneous Haber Bosch industrial processes on a vast scale, sequentially coupling these elementary reactions together with a single metal complex remains a major challenge for homogeneous molecular complexes. Here, we report that reaction of a chloro titanium triamidoamine complex with magnesium effects complete reductive cleavage of $N_{2}$ to give a dinitride dititanium dimagnesium ditriamidoamine complex. Tandem $\mathrm{H}_{2}$ splitting by a phosphine-borane Frustrated Lewis Pair (FLP) shuttles $\mathrm{H}$-atoms to the $\mathrm{N}^{3-}$, evolving $\mathrm{NH}_{3}$. Isotopic labelling experiments confirm $\mathrm{N}_{2}$ - and $\mathrm{H}_{2}$-fixation. Though not yet catalytic, these results give unprecedented insight into coupling $\mathrm{N}_{2}$ and $\mathrm{H}_{2}$-cleavage and $\mathrm{N}-\mathrm{H}$ bond formation steps together, highlight the importance of heterobimetallic cooperativity in $\mathrm{N}_{2}$-activation, and establish FLPs in $\mathrm{NH}_{3}$ synthesis.
\end{abstract}

Ammonia, $\mathrm{NH}_{3}$, is a key chemical feedstock for the production of a vast array of organo-nitrogen compounds. ${ }^{[1]}$ Nitrogenase enzymes produce $\mathrm{NH}_{3}$ from dinitrogen, $\mathrm{N}_{2}$, at ambient temperature and pressure, but this requires eight protons, $\mathrm{H}^{+}$, eight electrons, $\mathrm{e}^{-}$, and hydrolysis of sixteen ATP molecules per $\mathrm{N}_{2}{ }^{\left[{ }^{2]}\right.}$ In contrast, chemical industry produces $\mathrm{NH}_{3}$ using the Haber Bosch, $\mathrm{HB}$, process where $\mathrm{N}_{2}$ and $\mathrm{H}_{2}$ combine to give $\mathrm{NH}_{3}$ over heterogeneous metal catalysts. ${ }^{[2]}$ However, high temperatures and pressures are required in $\mathrm{HB} \mathrm{NH} \mathrm{N}_{3}$ synthesis, reflecting the challenge of cleaving the $\mathrm{N}_{2}$ triple bond.

Following the inception of $\mathrm{HB} \mathrm{NH}_{3}$ synthesis, considerable efforts have been made to gain insight into the chemical and physical processes involved. ${ }^{[3]}$ The rate-limiting step is $\mathrm{N}_{2}$ chemisorption on the metal catalyst and $\mathrm{N}-\mathrm{N}$ bond cleavage to give surface-bound nitrides, $\mathrm{N}^{3-}$, which then combine with adsorbed $\mathrm{H}$-atoms, produced by essentially barrier-less $\mathrm{H}_{2}$ dissociation on the metal surface, to give $\mathrm{NH}_{3}$. Because the reaction is heterogeneous it is difficult to study in atomic detail; however, there is evidence that multi-metallic sites are integral to $\mathrm{N}_{2}$ activation, and that the presence of various Group 1 and 2 metal oxides enhances catalyst reactivity by direct interaction with $\mathrm{N}_{2}$ or as "electronic" promoters. ${ }^{[3]}$ Thus, there is great interest in studying homogeneous complexes as surrogates for heterogeneous $\mathrm{HB} \mathrm{NH}$ synthesis as they can provide detailed information on reaction intermediates and mechanisms. ${ }^{[1-3]}$

$\mathrm{Ti}, \mathrm{V}, \mathrm{Mo}, \mathrm{Fe}, \mathrm{Ru}, \mathrm{Os}$, and Co complexes have been shown to catalytically reduce $\mathrm{N}_{2}$ to $\mathrm{NH}_{3}$ with $\mathrm{H}^{+} / \mathrm{e}^{-[4,5]}$. These catalytic cycles are based on sequential biomimetic-type protonation/reduction of $\mathrm{M}-\mathrm{N}_{2}$ linkages, contrasting to direct cleavage of $\mathrm{N}_{2} / \mathrm{H}_{2}$ in $\mathrm{HB}$ chemistry. Indeed, molecular species

[*] Dr L. R. Doyle, Dr A. J. Wooles, Prof. S. T. Liddle

School of Chemistry

The University of Manchester

Oxford Road, Manchester, M13 9PL, UK

E-mail: steve.liddle@manchester.ac.uk

Supporting information for this article is given via a link at the end of the document. that spontaneously cleave $\mathrm{N}_{2}$ to $\mathrm{N}^{3-}$ are rare, ${ }^{[6]}$ and none of the resulting metal-nitrides react with $\mathrm{H}_{2}$; other metal-nitrides can react with $\mathrm{H}_{2}$, to make a metal-amide, $\mathrm{M}-\mathrm{NH}_{2}$, or $\mathrm{NH}_{3}$, but they derive from azides rather than $\mathrm{N}_{2}$-splitting ${ }^{[7]}$ Very few complexes bind $\mathrm{N}_{2}$ and react further with $\mathrm{H}_{2}$, giving mono-protonation of coordinated $\mathrm{N}_{2},{ }^{[8]} \mathrm{NH}_{3}$ in low yield, ${ }^{[9]}$ or $\mathrm{NH}_{3}$ after exposure to $\mathrm{H}^{+}{ }^{[10]}$ Weakly acidic $\mathrm{M}-\mathrm{H}_{2}$ complexes can effect protonation of $\mathrm{M}-\mathrm{N}_{2}$ complexes to give $\mathrm{M}-\mathrm{NNH}_{2}$, ${ }^{[11]}$ and in one case $\mathrm{NH}_{3}$ was formed. ${ }^{[1 \mathrm{~b}]}$ Thus, in contrast to $\mathrm{HB} \mathrm{NH}_{3}$ synthesis, activating and cleaving $\mathrm{H}_{2}$ appears to be the impediment to progress. In an alternative approach that side-steps the $\mathrm{H}_{2}$-activation issue, transition metal hydrides can activate $\mathrm{N}_{2}$ and cleave it to $\mathrm{N}^{3-}$, [12] but no subsequent hydrogenation occurs, ${ }^{[12 a, b]}$ or reactions stop at $\mu-\mathrm{N}(\mathrm{H})$ or $\mu-\mathrm{NH}_{2}$ stages. $^{[9,12 \mathrm{c}, \mathrm{d}, 13]}$ It has been proposed that Frustrated Lewis Pairs (FLPs), that are capable of activating and splitting $\mathrm{H}_{2}$, could be combined with metal-based reductive cleavage of $\mathrm{N}_{2}{ }^{[14]}$ However, despite the burgeoning nature of FLP-mediated hydrogenations of organic substrates, ${ }^{[15]}$ combining this concept with $\mathrm{N}_{2}$ activation to make $\mathrm{NH}_{3}$ has remained an unmet goal, ${ }^{[16]}$ but mono-/di-protonation of metal- $\mathrm{N}_{2}$ units, borylation/silylation of M- $\mathrm{N}_{2}-\mathrm{B}$ FLPs, and a model for FLP$\mathrm{N}_{2}$ activation have now been realised. ${ }^{[17]}$

Here, we report homogeneous reductive cleavage of $\mathrm{N}_{2}$ to $\mathrm{N}^{3-}$ by a Ti-Mg complex supported by a simple triamidoamine ligand, and conversion of $\mathrm{N}^{3-}$ to $\mathrm{NH}_{3}$ using hydrogen from $\mathrm{H}_{2}$ split by a FLP. Heterobimetallic cooperativity facilitates reductive cleavage of $\mathrm{N}_{2}$, and by using a FLP the barrier to activating and cleaving $\mathrm{H}_{2}$ is overcome. The bridging nature of the nitride renders it amenable to full protonation to give $\mathrm{NH}_{3}$ that can be removed by vacuum distillation without the need for acidification, thereby introducing FLPs to $\mathrm{NH}_{3}$-synthesis.

Previously, ${ }^{[5]}$ we reported that $\left[\mathrm{Ti}\left(\operatorname{Tren}^{\mathrm{TMS}}\right) \mathrm{Cl}\right]\left[1, \operatorname{Tren}^{\mathrm{TMS}}=\right.$ $\left.\left\{\mathrm{N}\left(\mathrm{CH}_{2} \mathrm{CH}_{2} \mathrm{NSiMe}_{3}\right)_{3}\right\}^{3-}\right]$ can be reduced by $\mathrm{K}\left(\mathrm{K}\right.$ mirror, $\mathrm{KC}_{8}$, or $\left.\mathrm{KC}_{10} \mathrm{H}_{8}\right)$ to give [Ti(Tren $\left.{ }^{\mathrm{TMS}}\right)$ ]; this can bind to $\mathrm{N}_{2}$ to give the endon:end-on $\mathrm{N}_{2}$-complex $\left[\left\{\mathrm{Ti}\left(\operatorname{Tren}^{\mathrm{TMS}}\right)\right\}_{2}\left(\mathrm{~N}_{2}\right)\right]$ and further reduction with $\mathrm{K}$ gives $\left[\left\{\mathrm{Ti}\left(\operatorname{Tren}^{\mathrm{TMS}}\right)\right\}_{2}\left(\mathrm{~N}_{2} \mathrm{~K}_{2}\right)\right](2)$ that formally contains $\mathrm{N}_{2}{ }^{4-}$ where the $\mathrm{N}-\mathrm{N}$ bond is retained, Scheme 1. Nevertheless, 2 produces up to 18 equivalents of $\mathrm{NH}_{3}$ when treated with excess $\mathrm{H}^{+} / \mathrm{e}^{-\left[{ }^{[5]}\right]}$ Since it is clear that $\mathrm{K}\left(\mathrm{E}^{\circ}=-2.92\right)$ plays a cooperative, directing role in that reduction chemistry we investigated what effect replacing it with the milder reducing agent $M g\left(E^{\circ}=-2.37\right)$ would have. ${ }^{[18]}$ Thus, 1 was treated with excess $\mathrm{Mg}$ in $\mathrm{N}_{2}$ saturated 1,2-dimethoxyethane (DME) solvent, in the presence of ten equivalents of 1,4-dioxane, Scheme 1 . Brief sonication is required to initiate the reaction - we assume due to a kinetic delay from surface passivation of the $\mathrm{Mg}$ - as demonstrated by a colour change from orange to green. After a 3 day stir, a white precipitate forms with a purple-brown supernatant, which was concentrated and removed by filtration. The remaining solids were extracted with THF and filtered from the excess Mg and insoluble $\left[\mathrm{MgCl}_{2} \text { (1,4-dioxane) }\right]_{\infty}$ by-product. Removal of the THF and recrystallisation of the resulting solid from toluene gives colourless crystals of diamagnetic $\left[\left\{\mathrm{Mg}\left(\operatorname{Tren}^{\mathrm{TMS}}\right)\right\}_{2}\left\{\left(\mu_{3}-\mathrm{N}\right)_{2}(\mathrm{Ti})_{2}\right\}\right]$ (3), Scheme 1 , in a $\sim 20 \%$ crystalline yield. ${ }^{[19]}$ 


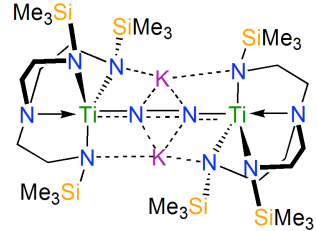

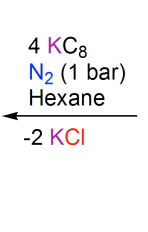

(1 bar) xane
$3 \mathrm{Mg}$

${ }^{14 / 15} \mathrm{~N}_{2}$ (1 bar)

DME

$\underset{-1 / \mathrm{n}\left[\mathrm{MgCl}_{2}(1,4-\text { dioxane })\right]_{\mathrm{n}}}{\longrightarrow}$

$\mathrm{Me}_{3}$

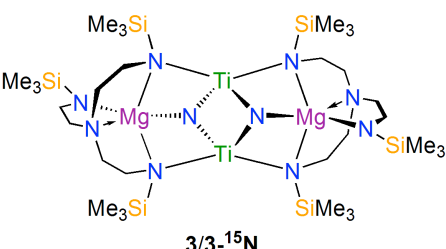

$3 / 3-{ }^{15} \mathrm{~N}$

Scheme 1. The Ti complex 1 gives different $\mathrm{N}_{2}$-reduction products depending on the nature of the reducing agent, producing the hydrazido complex 2 when reduced with $\mathrm{KC}_{8}$ (reference $5 \mathrm{j}$ ), or the dinitride complex 3 when reduced with elemental $\mathrm{Mg}$ (this work).

The solid-state structure of $\mathbf{3}$, Figure 1 , consists of two $\mathrm{Ti}$ centres, each coordinated by two $\left[\mathrm{Mg}\left(\operatorname{Tren}^{\mathrm{TMS}}\right)\right]^{-}$fragments (both $\left.\mathrm{K}^{1}-N: \mathrm{K}^{1}-N^{\prime}\right)$ and two $\mu_{3}-\mathrm{N}^{3-}$ ligands, which bridge both Ti centres and a $\mathrm{Mg}$ centre each. The resulting $\mathrm{Ti}(\mu-\mathrm{N})_{2} \mathrm{Ti}$ core is planar, with each pyramidalised nitride (sum of angles $=280.91(14)^{\circ}$ ) residing $1.04 \AA$ from the center of each $\mathrm{Ti}_{2} \mathrm{Mg}$ plane. Multinuclear ${ }^{1} \mathrm{H},{ }^{13} \mathrm{C}$, and ${ }^{29} \mathrm{Si}$ NMR spectra of $\mathrm{C}_{6} \mathrm{D}_{6}$ solutions of 3 exhibit sharp resonances within normal diamagnetic ppm ranges consistent with a closed-shell, diamagnetic $\mathrm{Ti}^{\mathrm{lV}} / \mathrm{Ti}^{\mathrm{IV}}$ complex, and are congruent with the solid-state structure in which the usual 3fold symmetry of $\left(\mathrm{Tren}^{\mathrm{TMS}}\right)^{3-}$ is lost and the two distinct $\mathrm{SiMe}_{3}$ environments are retained (2:1 ratio).

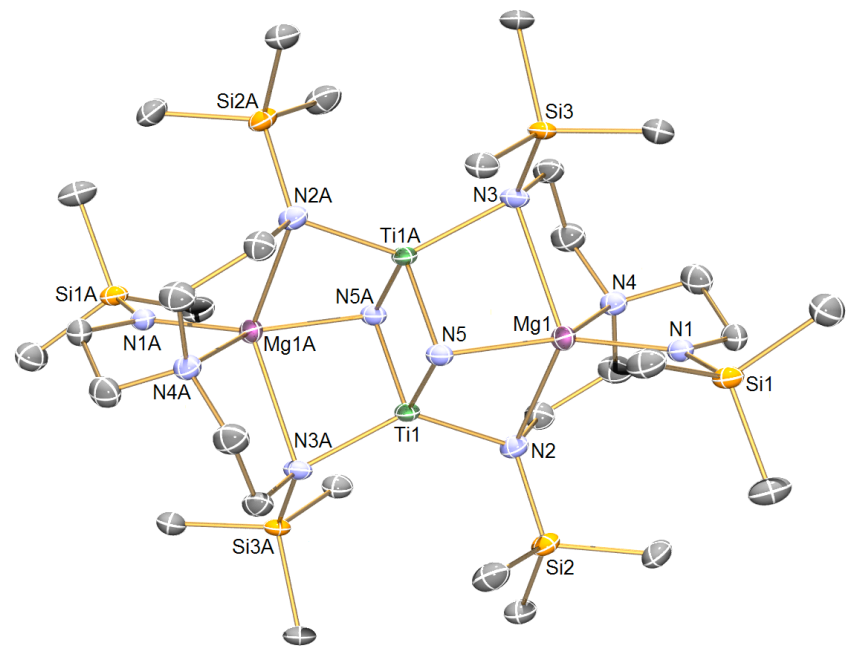

Figure 1. Molecular structure of $\left[\left\{\mathrm{Mg}\left(\operatorname{Tren}^{\mathrm{TMS}}\right)\right\}_{2}\left\{\left(\mu_{3}-\mathrm{N}\right)_{2}(\mathrm{Ti})_{2}\right\}\right](3)$ at $100 \mathrm{~K}$ with $50 \%$ probability ellipsoids. Hydrogen atoms are omitted for clarity. Selected distances $(\AA)$ and angles $\left({ }^{\circ}\right)$ are: Ti1-N2, 2.0147(19); Ti1-N3A, 2.0400(19); Ti1-N5, 1.8524(19); Ti1-N5A, 1.8532(19); Mg1-N1, 1.996(2); Mg1-N2, 2.518(2); Mg1-N3, 2.432(2); Mg1-N4, 2.1544(19); Mg1-N5, 2.1330(19); Ti1N5-Ti1A, 92.62(9); Ti1-N5-Mg1, 94.88(8); Ti1A-N5-Mg1, 93.41(8).

The nitride assignment and origin from incorporation of gaseous $\mathrm{N}_{2}$ into 3 was confirmed by repeating the synthesis under an atmosphere of ${ }^{15} \mathrm{~N}_{2}$; this reproducibly gives the ${ }^{15} \mathrm{~N}_{2}$ isotopologue $\left[\left\{\mathrm{Mg}\left(\operatorname{Tren}^{\mathrm{TMS}}\right)\right\}_{2}\left\{\left(\mu_{3-{ }^{-}}{ }^{15} \mathrm{~N}\right)_{2}(\mathrm{Ti})_{2}\right\}\right]\left(3-{ }^{15} \mathrm{~N}\right)$ that exhibits a singlet resonance at $405.4 \mathrm{ppm}$ in its ${ }^{15} \mathrm{~N}$ NMR spectrum in $\mathrm{C}_{6} \mathrm{D}_{6}$. The FTIR and Raman spectra of 3 and $3-{ }^{15} \mathrm{~N}$ do not exhibit any ${ }^{14} \mathrm{~N} /{ }^{15} \mathrm{~N}$ isotopically shifted absorptions in the range of $\mathrm{N}-\mathrm{N}$ single, double, or triple bond stretches, whilst a much weaker Raman band at $754 \mathrm{~cm}^{-1}(3)$ and $730 \mathrm{~cm}^{-1}\left(3-{ }^{15} \mathrm{~N}\right)$ is likely to be

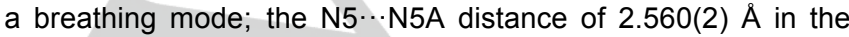
crystal structure further rules out the presence of any N-N bond in 3 and $3-{ }^{15} \mathrm{~N}$. Thus, the reduction of $\mathbf{1}$ to $\mathbf{3}$ involves the binding, activation, and complete six-electron reductive cleavage of a single molecule of $\mathrm{N}_{2}$, with concomitant rearrangement of the $\left(\operatorname{Tren}^{\mathrm{TMS}}\right)^{3-}$ ligand to support both $\mathrm{Ti}^{\mathrm{IV}}$ and $\mathrm{Mg}^{\text {II }}$ centres that in turn stabilise the two nitride ligands formed.

In order to verify the formulations of 3 and $3-{ }^{15} \mathrm{~N}$ and probe their reactivity, we performed acidification experiments assaying $\mathrm{NH}_{3}$ as its conjugate acid $\mathrm{NH}_{4}{ }^{+}$by ${ }^{1} \mathrm{H}$ quantified-NMR (qNMR) spectroscopy and the indophenol spectrophotometric method, Scheme 2. $\mathrm{NH}_{3}$ was isolated from the reaction mixture as $\mathrm{NH}_{4} \mathrm{Cl}$ via a standard base-distillation procedure employing a $\mathrm{HCl}$ trap. Acidification of $\mathbf{3}$ or $3-{ }^{15} \mathbf{N}$ in DME with ten equivalents of $\mathrm{HCl}(1$ $\mathrm{M}$ in $\mathrm{Et}_{2} \mathrm{O}, \mathrm{pK}_{\mathrm{a}}{ }^{\text {aq }}\left(\mathrm{Et}_{2} \mathrm{O} \cdot \mathrm{H}\right)^{+}=-3.59$ ) yielded $\mathrm{NH}_{4} \mathrm{Cl}$ (av. 1.94 eq., $97 \%$ ) or ${ }^{15} \mathrm{NH}_{4} \mathrm{Cl}$ (av. 1.84 eq., 92\%), respectively, in near quantitative yields. ${ }^{1} \mathrm{H}$ NMR spectra of the $\mathrm{HCl}$-trapped volatile fractions in DMSO revealed diagnostic triplet $\left(7.29 \mathrm{ppm}, J_{\mathrm{NH}}=\right.$ $51 \mathrm{~Hz})$ and doublet $\left(7.20 \mathrm{ppm}, J_{\mathrm{NH}}=71 \mathrm{~Hz}\right)$ resonances for ${ }^{14} \mathrm{NH}_{4}{ }^{+}$and ${ }^{15} \mathrm{NH}_{4}{ }^{+}$, respectively, and the ${ }^{15} \mathrm{~N}$ NMR spectrum for the latter reveals a quintet resonance at $-357.0 \mathrm{ppm}\left(J_{\mathrm{NH}}=71\right.$ $\mathrm{Hz}$ ). Notably, treating 3 with the weaker acid $\left[\mathrm{Cy}_{3} \mathrm{PH}\right][\mathrm{l}]$ (10 eq.; $\left.\mathrm{pK}_{\mathrm{a}}^{\mathrm{aq}}=9.7, \mathrm{H}_{2} \mathrm{O} ; \mathrm{pK}_{\mathrm{a}}{ }^{\mathrm{THF}}=9.7\right)^{[20]}$ also gave a good yield of $\mathrm{NH}_{4} \mathrm{Cl}$ (av. 1.44 eq., $72 \%$ ).

Encouraged by the reactivity of 3 and $3{ }^{15} \mathbf{N}$ towards $\mathrm{H}^{+}$we turned our attention towards effecting reactivity with $\mathrm{H}_{2}$. Complex 3 is unreactive towards $\mathrm{H}_{2}$ (1-4 bar) in various hydrocarbon, aromatic, or ethereal solvents. However, since the strongly basic nitride ligands in $\mathbf{3}$ were readily protonated by the relatively weak phosphonium acid $\left[\mathrm{Cy}_{3} \mathrm{PH}\right]\left[{ }^{\left[{ }^{[5]}\right]}\right.$ we surmised that 3 might be reacted with $\mathrm{H}_{2}$ in tandem via the $\mathrm{H}_{2}$-activated complex $\left[{ }^{\mathrm{t}} \mathrm{Bu} \mathrm{u}_{3} \mathrm{PH}\right][\mathrm{HBCF}]\left(\mathrm{BCF}=\mathrm{B}\left(\mathrm{C}_{6} \mathrm{~F}_{5}\right)_{3}\right),{ }^{\left[{ }^{21]}\right.}$ generated from the known $\mathrm{P}^{\mathrm{t}} \mathrm{Bu}_{3} / \mathrm{BCF}$ FLP system using $\mathrm{H}_{2}$ in toluene. ${ }^{[19]}$ Gratifyingly, treatment of 3 with [ ${ }^{t} \mathrm{Bu}_{3} \mathrm{PH}$ ] $\mathrm{HBCF}$ ] (6 eq.) in THF yielded $\mathrm{NH}_{3}$ (0.97 eq., $49 \%$ ), isolated from the reaction by distillation onto frozen $\mathrm{DCl}$ (200 eq.; $2 \mathrm{M}$ in $\mathrm{Et}_{2} \mathrm{O}$ ) to form $\mathrm{NH}_{\mathrm{x}} \mathrm{D}_{\mathrm{y}} \mathrm{Cl}\left(\mathrm{NH}_{3} \mathrm{DCl}\right.$ expected), Scheme 2. The $\mathrm{D}^{+}$trapping acid was employed in order to unequivocally differentiate chemically this step from the preceding $\mathrm{NH}_{3}$-forming reaction with $\left[{ }^{\mathrm{t}} \mathrm{Bu}_{3} \mathrm{PH}\right][\mathrm{HBCF}]$. Analogously, reactions between $3 / 3-{ }^{15} \mathrm{~N}$ and $\left[{ }^{t} \mathrm{Bu} u_{3} P D\right][D B C F]$ (synthesized from $\left.\mathrm{D}_{2}\right)$ generated $\mathrm{ND}_{3}\left(\mathrm{~N}={ }^{14} \mathrm{~N} /{ }^{15} \mathrm{~N}, 0.76-1.25\right.$ eq., 38-63\%), trapped with $\mathrm{HCl}$ to form $\mathrm{NH}_{\mathrm{x}} \mathrm{D}_{\mathrm{y}} \mathrm{Cl}\left(\mathrm{NHD}_{3} \mathrm{Cl}\right.$ expected). The ammonium salts were redissolved in dry DMSO- $\mathrm{d}_{6}$ and analysed by ${ }^{1} \mathrm{H}$ qNMR, then subsequently reanalysed after conversion to $\mathrm{NH}_{4} \mathrm{Cl}$ by hydrolysis with $\mathrm{HCl}_{a q}$ to effect complete $H / D$ exchange. This enabled a comparison of the relative ${ }^{1} \mathrm{H}$ integrals for the $\mathrm{NH}_{x} \mathrm{D}_{y} \mathrm{Cl}$ resonances before $(x+y=4)$ and after $(x=4)$ hydrolysis, from which the values of both $x$ and $y$ could be determined (see $\mathrm{SI}$ ). Thus, incorporation of either $\mathrm{H}^{+}$from $\left[{ }^{t} \mathrm{Bu}_{3} \mathrm{PH}\right][\mathrm{HBCF}]$ or $\mathrm{D}^{+}$from $\left.{ }^{\mathrm{t}} \mathrm{Bu}_{3} \mathrm{PD}\right][\mathrm{DBCF}]$ into the ammonium product is unequivocally demonstrated, although the quantified values are lower than expected due to some H/D exchange. This $H / D$ exchange occurs prior to the hydrolysis reaction, which cannot be avoided by variation of the experimental procedure, 


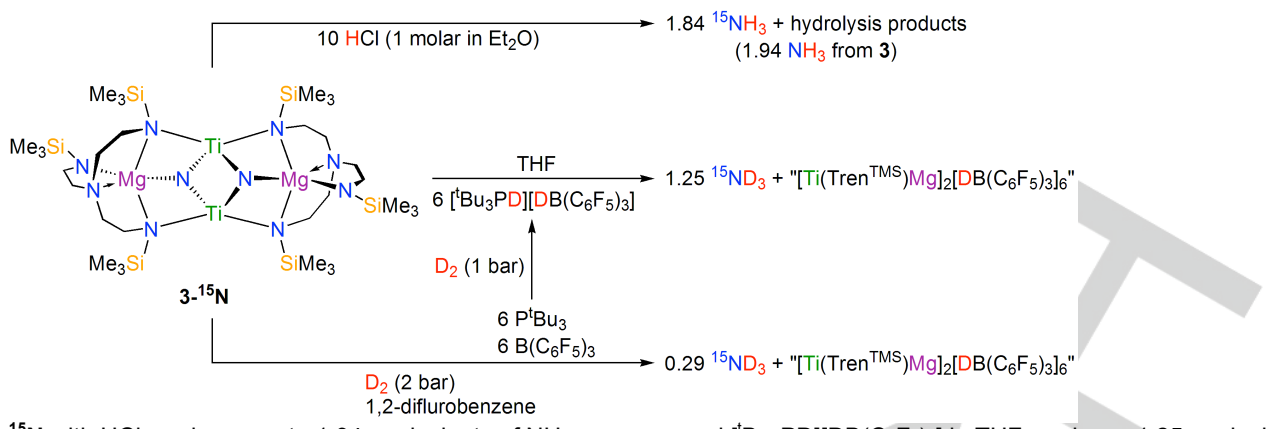

Scheme 2. The reaction of $3{ }^{15} \mathrm{~N}$ with $\mathrm{HCl}$ produces up to 1.94 equivalents of $\mathrm{NH}_{3}$, pre-prepared $\left[{ }^{t} B u_{3} \mathrm{PD}\right]\left[\mathrm{DB}\left(\mathrm{C}_{6} \mathrm{~F}_{5}\right)_{3}\right]$ in $\mathrm{THF}$ produces 1.25 equivalents of ${ }^{15} \mathrm{ND}_{3}$, whereas in situ treatment of $3-{ }^{15} \mathrm{~N}$ with $\mathrm{P}^{\mathrm{t}} \mathrm{Bu}_{3}, \mathrm{~B}\left(\mathrm{C}_{6} \mathrm{~F}_{5}\right)_{3}$, and $\mathrm{D}_{2}$ produces 0.29 equivalents of ${ }^{15} \mathrm{ND}_{3}$.

but the extent of $\mathrm{H}-\mathrm{D}$ and $\mathrm{D}-\mathrm{H}$ exchange essentially mirror each other internally validating this hypothesis. Further, one possible cause is thought to be the co-distillation of $\mathrm{NH}_{3}$ with the $\mathrm{P}^{\mathrm{t}} \mathrm{Bu}_{3}$ by-product, which was chemically trapped with the $\mathrm{HCl}$ or $\mathrm{DCl}$ acid as $\left[{ }^{t} \mathrm{Bu}_{3} \mathrm{PH}\right][\mathrm{Cl}]$ and $\left[{ }^{t} \mathrm{Bu} u_{3} \mathrm{PD}\right][\mathrm{Cl}]$, respectively $\left({ }^{31} \mathrm{P}\left\{{ }^{1} \mathrm{H}\right\} \mathrm{NMR}\right.$ (DMSO-d $_{6}$ ): $51.68 \mathrm{ppm}, \mathrm{s}$; and $50.88 \mathrm{ppm}, \mathrm{t}, \mathrm{J}_{\mathrm{PD}}=70 \mathrm{~Hz}$, respectively). Thus, partial $\mathrm{H}^{+} / \mathrm{D}^{+}$exchange may occur within an equilibrium mixture of $\mathrm{NH}_{3} / \mathrm{NH}_{4}{ }^{+}\left(\mathrm{pK} \mathrm{a}=9.3, \mathrm{H}_{2} \mathrm{O}\right)$ and $\left.{ }^{\mathrm{t}} \mathrm{Bu}_{3} \mathrm{P} /{ }^{\mathrm{t}} \mathrm{Bu}_{3} \mathrm{PH}^{+}\left({ }^{\mathrm{t}} \mathrm{Bu} \mathrm{B}_{3} \mathrm{PH}\right]^{+}, \mathrm{pK} \mathrm{a}=11.4, \mathrm{H}_{2} \mathrm{O} ; \mathrm{pK}_{\alpha}{ }^{\mathrm{THF}}=10.7\right){ }^{[20]}$

Having established tandem $\mathrm{N}_{2}$ and $\mathrm{H}_{2}$ activation prior to conversion to $\mathrm{NH}_{3}$, a preliminary in situ reaction suggests that FLP-chemistry has potential to emerge as an effective vehicle in this area. Hydrogenation of $3-{ }^{15} \mathrm{~N}$ performed in situ using $\mathrm{P}^{\mathrm{t}} \mathrm{Bu}_{3} / \mathrm{BCF}$ in 1,2-difluorobenzene (DFB) under a $\mathrm{D}_{2}$ atmosphere ( $\sim$ bar) and volatile-trapping with frozen $\mathrm{HCl}$ yielded $\mathrm{NH}_{4} \mathrm{Cl}$ [0.29 \pm 0.05$)$ eq., $15 \%]$, Scheme 2. At that level D-incorporation could not be unequivocally confirmed due to relatively increased $H / D$ exchange occurring under these conditions. The lower yield for an in situ tandem reaction rather than stepwise suggests that yet to be determined competitive side-reactions are operating. However, it is encouraging that $\mathrm{NH}_{3}$ could be isolated by vacuum distillation from this preliminary, unoptimised experiment

The observed colour change of orange to green then purple-brown when 1 is reduced with $\mathrm{Mg}$ suggests that, as is the case for K-mediated reduction that gives $2^{\left[{ }^{[j]}\right]} \mathbf{1}$ is reduced to [Ti( $\left.\left.\operatorname{Tren}^{\mathrm{TMS}}\right)\right]$, which is green, and reversibly binds $\mathrm{N}_{2}$ to form $\left[\left\{\mathrm{Ti}\left(\operatorname{Tren}^{\mathrm{TMS}}\right)\right\}_{2}\left(\mathrm{~N}_{2}\right)\right]$ transiently. Further reduction with magnesium then gives $\mathbf{3}$, in which complete reductive cleavage of $\mathrm{N}_{2}$ to $\mathrm{N}^{3-}$ has occurred, in contrast to partial reduction by $\mathrm{K}$ to afford 2; this may be accounted for by the more polarizing nature of $\mathrm{Mg}^{2+}$ compared to $\mathrm{K}^{+}$, since the former has a high charge to radius ratio, possibly resulting in additional polarization of the $\mathrm{N}_{2}$ molecule promoting its complete rupture. The fact that $\mathrm{K}$ reduction of 1 gives $\mathrm{N}_{2}^{4-}$ with retention of a N-N bond but milder magnesium gives complete cleavage to $\mathrm{N}^{3-}$ underscores how cooperative effects are key to $\mathrm{N}_{2}$-activation. ${ }^{[10 a]}$ Although high valent transition metal nitrides are often unreactive towards $\mathrm{H}_{2}$, on account of their strong $\mathrm{M} \equiv \mathrm{N}$ triple bonds ${ }^{[\mathrm{bb}]}$ the polymetallic bridging nitrides in $\mathbf{3}$ are readily fully protonated with strong acid to give quantitative liberation of $\mathrm{NH}_{3}$ demonstrating complete $\mathrm{N}$ $\mathrm{N}$ dissociation and two highly basic nitrides in $\mathbf{3}$. Thus, when $\mathbf{3}$ is treated with $\left[{ }^{t} \mathrm{Bu}_{3} \mathrm{PH}\right][\mathrm{HBCF}]$ (or $\left[{ }^{\mathrm{t}} \mathrm{Bu}_{3} \mathrm{PD}\right][\mathrm{DBCF}]$ ), all three successive protonation steps occur from $\mathrm{N}^{3-}$ to $\mathrm{NH}_{3}$ (or $\mathrm{ND}_{3}$ ), which can be isolated from the reaction by vacuum distillation, circumventing the need for additional acid to be employed. ${ }^{[22]}$ These points can be related to HB chemistry, where the ability to reductively cleave $\mathrm{N}_{2}$ to $\mathrm{N}^{3-}$ and any subsequent reactivity is dominated by polymetallic activation and heterobimetallic cooperative effects. ${ }^{[2 a, 3,10 a, 10 b]}$ By combining FLP-splitting of $\mathrm{H}_{2}$ with Ti-Mg-mediated cleavage of $\mathrm{N}_{2}$ to produce $\mathrm{NH}_{3}$ the heterogeneous hydrogenation of $\mathrm{N}_{2}$ in $\mathrm{HB}$ chemistry has been partially replicated, adding $\mathrm{NH}_{3}$-synthesis, prominent by its absence, to the family of FLP hydrogenation reactions. ${ }^{[14,16]}$

In conclusion, by harnessing a cooperative combination of $\mathrm{Ti}$ and $\mathrm{Mg}$ we have cleaved $\mathrm{N}_{2}$ to two nitrides in a six-electron reduction. The resulting nitrides are basic and liberate $\mathrm{NH}_{3}$ when treated with acids. By employing a FLP to cleave $\mathrm{H}_{2}$ we have sidestepped an apparent barrier to $\mathrm{H}_{2}$-activation, enabling the resulting phosphonium-borohydride to fully protonate the nitrides to give $\mathrm{NH}_{3}$, thus establishing FLPs in $\mathrm{NH}_{3}$ synthesis from $\mathrm{N}_{2}$ activation and hydrogenation chemistry. The polymetallic nature and reactivity of this $\mathrm{N}_{2}$-fixation chemistry, which uniquely combines key heterogeneous HB steps together at a single homogeneous metal complex, when most complexes can only execute an individual reaction step, provides a simple molecular system amenable to further atomic-level study. ${ }^{[23]}$

\section{Acknowledgements}

We gratefully acknowledge the UK EPSRC (grants EP/M027015/1 and EP/P001286/1), ERC (grant CoG612724), Royal Society (grant UF110005), and The University of Manchester for generous funding and support.

Keywords: Dinitrogen reduction $\bullet$ Frustrated Lewis pairs $\bullet$ Titanium $•$ Ammonia $\bullet$ Nitrogen fixation

[1] K. C. MacLeod, P. L. Holland, Nat. Chem. 2013, 5, 559.

[2] a) S. L. Foster, S. I. Perez Bakovic, R. D. Duda, S. Maheshwari, R. D. Milton, S. D. Minteer, M. J. Janik, J. N. Renner, L. F. Greenlee, Nat. Cat. 2018, 1, 490-500; b) R. J. Burford, M. D. Fryzuk, Nat. Rev. Chem. 2017, $1,0026$.

[3] H. -P. Jia, E. A. Quadrelli, Chem. Soc. Rev. 2014, 43, 547.

[4] D. V. Yandulov, R. R. Schrock, Science 2003, 301, 76.

[5] a) K. Arashiba, Y. Miyake, Y. Nishibayashi, Nat. Chem. 2011, 3, 120; b) Y. Nishibayashi, Dalton Trans. 2018, 47, 11290; c) J. Fajardo Jr, J. C. Peters, J. Am. Chem. Soc. 2017, 139, 16105; d) A. Eizawa, K. Arashiba, H. Tanaka, S. Kuriyama, Y. Matsuo, K. Nakajima, K. Yoshizawa, Y. Nishibayashi, Nat. Commun. 2017, 8, 14874; e) S. Kuriyama, K. Arashiba, H. Tanaka, Y. Matsuo, K. Nakajima, K. Yoshizawa, Y. Nishibayashi, Angew. Chem. Int. Ed. 2016, 55, 14291; f) S. Kuriyama, K. Arashiba, K. Nakajima, Y. Matsuo, H. Tanaka, K. Ishii, K. Yoshizawa, Y. Nishibayashi, Nat. Commun. 2016, 7, 12181; g) J. S. Anderson, J. Rittle, J. C. Peters, Nature 2013, 501, 84; h) P. J. Hill, L. R. Doyle, A. D. 
Crawford, W. K. Myers, A. E. Ashley, J. Am. Chem. Soc. 2016, 138, 13521 ; i) Y. Sekiguchi, K. Arashiba, H. Tanaka, A. Eizawa, K. Nakajima K. Yoshizawa, Y. Nishibayashi, Angew. Chem. Int. Ed. 2018, 130, 9202; j) L. R. Doyle, A. J. Wooles, L. C. Jenkins, F. Tuna, E. J. L. McInnes, S. T. Liddle, Angew. Chem. Int. Ed. 2018, 57, 6314

[6] a) C. E. Laplaza, C. C. Cummins, Science 1995, 268, 861; b) A. Zanotti-Gerosa, E. Solari, L. Giannini, C. Floriani, A. Chiesi-Villa, C. Rizzoli, J. Am. Chem. Soc. 1998, 120, 437; c) G. K. B. Clentsmith, V. M. E. Bates, P. B. Hitchcock, F. G. N. Cloke, J. Am. Chem. Soc. 1999, 121, 10444; d) I. Korobkov, S. Gambarotta, G. P. A. Yap, Angew. Chem. Int. Ed. 2002, 41, 3433; e) L. Morello, P. Yu, C. D. Carmichael, B. O. Patrick, M. D. Fryzuk, J. Am. Chem. Soc. 2005, 127, 12796; f) I. Klopsch, M. Finger, C. Würtele, B. Milde, D. B. Werz, S. Schneider, J. Am. Chem. Soc. 2014, 136, 6881; g) M.-A. Légaré, G. Bélanger-Chabot, R. D. Dewhurst, E. Welz, I. Krummenacher, B. Engels, H. Braunschweig, Science 2018, 359, 896.

[7] a) J. Schöffel, A. Y. Rogachev, S. D. George, P. Burger, Angew. Chem. Int. Ed. 2009, 48, 4734; b) B. Askevold, J. T. Nieto, S. Tussupbayev, M. Diefenbach, E. Herdtweck, M. C. Holthausen, S. Schneider, Nat. Chem. 2011, 3, 532.

[8] M. D. Fryzuk, J. B. Love, S. T. Rettig, V. G. Young, Science 1997, 275, 1445.

[9] J. A. Pool, E. Lobkovsky, P. J. Chirik, Nature 2004, 427, 527.

[10] a) M. M. Rodriguez, E. Bill, W. W. Brennessel, P. L. Holland, Science 2011, 334, 780; b) M. Falcone, L. Chatelain, R. Scopelliti, I. Zivkovic, M. Mazzanti, Nature 2017, 547, 332.

[11] a) G. Jia, R. H. Morris, C. T. Schweitzer, Inorg. Chem. 1991, 30, 593; b) Y. Nishibayashi, S. Iwai, M. Hidai, Science 1998, 279, 540.

[12] a) F. Akagi, T. Matsuo, H. Kawaguchi, Angew. Chem. Int. Ed. 2007, 46, 8778; b) Y. Ishida, H. Kawaguchi, J. Am. Chem. Soc. 2014, 136, 16990 ; c) T. Shima, S. Hu, G. Luo, X. Kang, Y. Luo, Z. Hou. Science 2013, 340, 1549; d) B. Wang, G. Luo, M. Nishiura, S. Hu, T. Shima, Y. Luo, Z. Hou, J. Am. Chem. Soc. 2017, 139, 1818.

[13] a) S. D. Brown, M. P. Mehn, J. C. Peters, J. Am. Chem. Soc. 2005, 127, 13146; b) G. B. Nikiforov, I. Vidyaratne, S. Gambarotta, I. Korobkov, Angew. Chem. Int. Ed. 2009, 48, 7415; c) M. Falcone, L. N. Poon, F. F. Tirani, M. Mazzanti, Angew. Chem. Int. Ed. 2018, 57, 3697.
[14] M. Hölscher, W. Leitner, Chem. Eur. J. 2017, 23, 11992.

[15] D. W. Stephan, Science 2016, 354, aaf229.

[16] R. L. Melen, Angew. Chem. Int. Ed. 2018, 57, 880

[17] a) J. B. Geri, J. P. Shanahan, N. K. Szymczak, J. Am. Chem. Soc. 2017, 139, 595; b) M. Tamizmani, C. Sivasankar, Eur. J. Inorg. Chem. 2017, 4239; c) A. Simonneau, R. Turrel, L. Vendier, M. Etienne, Angew. Chem. Int. Ed. 2017, 56, 12268; d) C. Tang, Q. Liang, A. R. Jupp, T. C Johnstone, R. C. Neu, D. Song, S. Grimme, D. W. Stephan, Angew. Chem. Int. Ed. 2017, 56, 16588.

[18] A. J. de Bethune, N. A. Swendeman Loud in Standard Aqueous Electrode Potentials and Temperature Coefficients at 25 Degrees, Clifford A. Hampel Publisher, Massachusetts, 1964.

[19] The low isolated yield of $\mathbf{3}$ is partly due to these necessary purification steps, including removal of unidentified reaction products - along with some 3 - in the DME reaction solution. Several issues precluded assessment of the conversion to 3 by NMR spectroscopy: the reaction solvent must be DME; some 3 precipitates from the reaction; and the other products obfuscate NMR assignment and integration.

[20] K. Abdur-Rashid, T. P. Fong, B. Greaves, D. G. Gusev, J. G. Hinman, S. E. Landau, A. J. Lough, R. H. Morris, J. Am. Chem. Soc. 2000, 122, 9155

[21] G. C. Welch, D. W. Stephan, J. Am. Chem. Soc. 2007, 129, 1880.

[22] The identity of the Ti-Mg by-product after $\mathrm{NH}_{3}$ is removed is currently unknown since it is an intractable yellow oil, but ${ }^{11} \mathrm{~B}$ and ${ }^{19} \mathrm{~F} N M R$ spectroscopies unequivocally confirm the presence of the [HBCF] anion, so the product is likely to empirically be $\left[\mathrm{Ti}\left(\mathrm{Tren}^{\mathrm{TMS}}\right) \mathrm{Mg}\right]_{n}[\mathrm{HBCF}]_{3 n}$. Supporting this, on one occasion standing the yellow oil in THF for 6 weeks resulted in the isolation of highly disordered crystals of $\left[\mathrm{Mg}(\mathrm{THF})_{6}\right][\mathrm{HBCF}]_{2}$ (4) in low yield (see the Supporting Information), which implies $\operatorname{Tren}^{\mathrm{TMS}}$-transfer to give $\left[\right.$ Ti $\left.\left(\operatorname{Tren}^{\text {TMS }}\right)(\mathrm{HBCF})\right]$

[23] CCDC 1859461 (3) and 1859462 (4) contain the supplementary crystallographic data for this paper. These data are provided free of charge by the Cambridge Crystallographic Data Centre. All other data are available from the corresponding author on request. 


\section{Entry for the Table of Contents}

\section{COMMUNICATION}

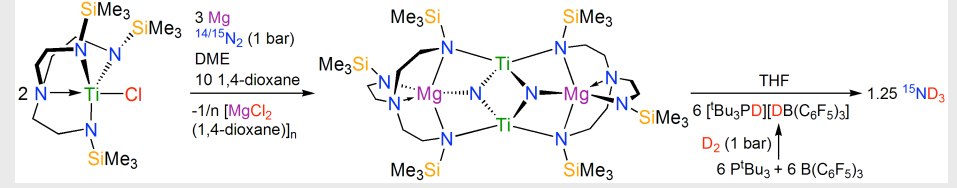

Text for Table of Contents
Laurence R. Doyle, Ashley J. Wooles, and Stephen T. Liddle*

Page No. - Page No.

Bimetallic Cooperative Cleavage of Dinitrogen to Nitride and Tandem Frustrated Lewis Pair Hydrogenation to Ammonia 